\title{
DE INTEGRATIE VAN WESTINDISCHE \\ IMMIGRANTEN IN GROOT-BRITTANNIË EN IN NEDERLAND
}

In verband met het beperkte absorptievermogen van het dichtbevolkte Groot-Brittannië, heeft haar regering in augustus I965 een nieuwe beperkende immigratiewet uitgevaardigd - in aansluiting aan soortgelijke maatregelen in 1962 - om de immigrantenstroom uit de Gemenebestlanden in te dammen. Volgens de inhoud van het desbetreffende Witboek van de Britse regering Immigration from the Commonwealth kan per jaar een quotum van totaal 8.500 immigranten met hun vrouwen en kinderen beneden de leeftijd van I6 jaar (of andere afhankelijke gezinsleden) uit alle Gemenebestlanden tezamen voor toelating in Groot-Brittannië in aanmerking komen. Voorwaarde voor de toelating is, dat zij hetzij speciale bevoegdheden of kundigheden bezitten (categorie B), hetzij een specifieke betrekking als geschoold of ongeschoold werknemer komen bezetten (categorie A).

Tussen I955 en I juli I962, dus vóór de inwerkingtreding van de eerste immigratiewet voor Gemenebestburgers, zo blijkt uit het bovenstaande Witboek, immigreerden in Groot-Brittannië in totaal circa een half miljoen mensen uit het Caraïbisch Gebied, Azië, Oost- en West-Afrika en het Middellandse Zeegebied. Maar de immigratiewet van 1962 had niet het verwachte effect, de immigratie uit die gebieden drastisch af te remmen. Tussen januari 1963 en juni 1965 immigreerden in Groot-Brittannië I88.00o Gemenebestburgers, van wie circa $20 \%$ (38.000) uit Canada, Australië en Nieuw-Zeeland, en circa $80 \%$ (I50.000) uit andere Gemenebestlanden met een overwegend gekleurde bevolking.

Het mislukken van de opzet om de groeiende immigrantenstroom tot geringere proporties terug te brengen, was te wijten aan een wijziging, in casu in de samenstelling der immigrantengroepen. Zo overtreffen bijvoorbeeld sedert $195^{8}$ de vrouwen en kinderen in aantal de mannelijke immigranten uit West-Indië, hetgeen erop wijst, dat de meerderheid der Westindiërs voorlopig 
niet aan terugkeer naar hun geboorteland denkt (WooD, I960, p. Io). Het aantal Gemenebest-immigranten blééf toenemen, wat tenslotte leidde tot de uitvaardiging van de Commonwealth Immigrants Act van augustus 1965 .

Het is begrijpelijk, dat de integratie in het Britse socio-economische en culturele leven van dergelijke aantallen immigranten, met niet alleen van het Britse maar ook onderling totaal verschillende levenspatronen, een overstelpend aantal problemen medebrengt. Een indruk van de aard van die problemen krijgt men uit de in het genoemde Witboek voorgestelde maatregelen vanwege de regering en de lokale autoriteiten, die ten doel hebben:

re. sociale spanningen te voorkomen;

2e. discriminerende voorwaarden in aanvragen om arbeidskrachten door werkgevers te bestrijden;

3 . ongewenste concentraties van vestiging tegen te gaan;

4e. bestaande educatieve maatstaven op de scholen te handhaven;

5e. medisch onderzoek en behandeling van binnenkomende immigranten te bevorderen.

De eerste vier aspecten van het Britse integratiebeleid ten aanzien van de immigranten willen wij in dit artikel nader bezien.

Vergelijking van de situatie van de grootste Westindische immigrantengroep in Groot-Brittannië, de Jamaicanen, met die van de Surinaamse immigranten in Nederland, brengt een aantal interressante verschillen aan het licht. Van de vermelde in totaal 500.000 recente Gemenebest-immigranten in Groot-Brittannië gerekend vanaf 1955 - is meer dan de helft, namelijk 300.000 , uit de voormalige Brits-Westindische gebieden afkomstig. En van die 300.000 Westindiërs wonen er in Londen ruim 135.000, van wie circa de helft Jamaicanen (volgens de volkstelling van I963) (Patterson, I963, p. 43, 420). Schatten wij het aantal Jamaicanen in Groot-Brittannië op I50.00o, dan blijkt, dat dit bijna 8.7 procent van het aantal inwoners van Jamaica (1963: ca. I.725.000) bedraagt (Jamaica, I962). Het aantal Surinamers in Nederland bedroeg einde december I965: circa Ir.6oo personen, van wie 6.450 personen te Amsterdam waren gevestigd. Dit betekent dat ruim 3,5 procent van de bevolking van Suriname (1965: ca. $330.000)$ in Nederland woont. ${ }^{1}$ De vergelijking van deze twee

1 Gegevens: Kabinet van de Gevolmachtigde Minister van Suriname in Nederland. 
groepen Westindiërs, de Jamaicaanse en de Surinaamse, voornamelijk Creoolse immigranten, heeft betrekking op de in de lagere beroepsgroepen arbeidende immigrantenbevolking. De ethnische verschillen binnen de twee bedoelde groepen zullen wij buiten beschouwing laten.

De Surinamers in Nederland en de Jamaicanen in Engeland moeten in vele opzichten aan overeenkomstige migratiemoeilijkheden het hoofd bieden. Beide groepen worden tot aanpassing en hersocialisatie genoopt, met andere woorden tot het aanleren van nieuwe gedragspatronen, normen en waarden, iets wat zij met hun in hun geboorteland verworven kennis van het overzeese voormalige moederland niet hadden verwacht. Maar de bijzondere vormen van deze aanpassing in de beide Europese industrielanden lopen nogal uiteen. Patronen van sociale mobiliteit, statusverschuivingen, klassenormen, woongewoonten, en dergelijke, liggen in Nederland en Groot-Brittannië niet gelijk, en de immigratieproblemen vertonen dienovereenkomstige verschillen.

Daarnaast zijn ook de motieven voor migratie bij Jamaicanen en Surinamers niet geheel gelijk. Al is het uiteindelijke doel dan ook bij beide groepen: verbetering van levensomstandigheden in economisch en maatschappelijk opzicht, de middelen tot het bereiken van dat doel zijn niet bij beide groepen dezelfde. Deze middelen zijn sterk georiënteerd op in de koloniale periode ontwikkelde statusaspiraties.

De Jamaicanen, een arm maar vitaal migrantenvolk, trekken vanouds voor werkgelegenheid naar de andere Caraïbische gebieden en vooral naar de Verenigde Staten van Noord-Amerika (de 'Golden Door'), om met harde arbeid de achtergebleven gezinsleden financiëel te steunen (EGGINTON, I957, p. 30, 49; PATTERSON, I963, p. I3 e.v.). Met economische middelen kan het gezin een middenklasse-status handhaven of bereiken.

De Surinamers, anderzijds, die niet zoals de Jamaicanen met nijpende armoede worden geconfronteerd, hebben traditioneel een groot ontzag voor door studie verworven kennis als middel tot statusverhoging. Hieruit laat zich verklaren, dat vele Surinamers zichzelf en anderen ervan weten te overtuigen, dat zij niet alleen naar Europa gaan om arbeid en daarmede economische verbetering te zoeken, maar daarnaast een bepaalde studie voor ogen hebben. En velen lukt het, dit plan metterdaad te volvoeren (TholenaAR-VAn RaAlte, I963, p. I9 e.v.; Bayer, I965, p. 23, 24). 
Misschien geeft dit accentverschil in de sociale, respectievelijk economische motieven van de twee groepen Westindische migranten ons de sleutel tot een gedeeltelijke verklaring van het feit, dat de Surinamers wèl en de Jamaicanen géén eigen formele politieke en recreatieve verenigingen in het nieuwe land van vestiging hebben gesticht (PatTerson, I963, p. I3 e.v.). De in het verleden in crisissituaties opgerichte Jamaicaanse verenigingen hadden altijd een kortstondig leven. Tevens echter dienen wij in aanmerking te nemen de áánwezigheid in Suriname en de àfwezigheid op Jamaica van traditionele modellen voor dit soort verenigingen. En tenslotte bestaat er in Groot-Brittannië - in navolging van het Engelse cultuurpatroon - een grotere sociale distantie dan in Nederland tussen de klasse van Westindische intellectuelen, waaruit leiders voor eigen verenigingen moeten voortkomen, en de meestal uit de middenklasse afkomstige, maar in het Europese industrieland tot de lagere klassen gedaalde immigranten.

Hoe vindt de integratie van deze Jamaicaanse immigranten dan plaats in Groot-Brittannië, waar dus buiten de officiële gezagsorganen en sociale instellingen geen Westindische immigrantenverenigingen bestaan, zoals in Nederland het geval is, om als kanalen te dienen voor communicatie met, en voorlichting te geven over de nieuwe omringende maatschappij? Ten behoeve van de integratie in de absorberende Britse samenleving wordt gebruik gemaakt van instituties zoals de zogenaamde, door de Westindiërs zelve gestichte 'harmony-clubs' en 'interracial social clubs' (GLASs, I960, p. 202-207). De bedoelde clubs hebben niet alleen ten doel: de bestrijding van vooroordeel en discriminatie en de vermindering van spanning tussen autochtonen en immigranten door hen nader tot elkaar te brengen; maar zij dienen tevens om de vorming van formele immigrantenverenigingen te ontmoedigen. ${ }^{1}$ Hoewel Groot-Brittannië gaarne de ethnische kleurschakeringen binnen zijn grenzen zou handhaven, dwingt toch het spookbeeld van de ethnische segmentering zijn regering tot een integratiebeleid, dat assimilatie van de immigranten tot gevolg moet hebben. Ethnische segmentering van de Britse samenleving zou betekenen, dat elke ethnische groep afzonderlijk zou zijn gestratificeerd in verscheidene sociale klassen met eigen normen en eigen levensstijl.

De Jamaicaanse immigrant wil niets liever dan volkomen Brits zijn en als zodanig worden beschouwd. Hij kent ook inderdaad

1 Mededeling van John Fraser, Deputy Secretary, National Committee for Commonwealth Immigrants, London, april 1966. 
geen andere taal dan het Engels en geen andere cultuur dan een Engels-georiënteerde sub-cultuur. Hij vindt het overbodig en onjuist, dat zijn kinderen die alleen Engels kennen, in immigrantenklasjes worden geplaatst tezamen met Indische, Pakistaanse, Westafrikaanse en andere immigrantenkinderen die thuis geen Engels hebben geleerd. Wij zullen echter nog aantonen dat de Jamaicaanse immigrant uit de lagere klasse bepaalde cultuurtrekken, die op het terrein van zijn religie liggen, onder ontmoedigende omstandigheden handhaaft.

Hoewel dus de Britse regering vastbesloten is om tot een bevredigende integratie van haar gekleurde minderheden te komen, en de autoriteiten de mouwen opstropen om de onlangs onwettig verklaarde discriminatie definitief te gaan begraven, blijkt het mogelijk te zijn bepaalde vormen daarvan via achterwegen toch toe te passen. Een werkgever moet niet proberen om tot de officiële arbeidsbeurzen, die onder het Ministerie van Arbeid ressorteren, een aanvrage te richten voor uitsluitend blank personeel, want daarvan wordt geen nota genomen. Gekleurde werknemers worden niet in een aparte categorie gerubriceerd (GLASs, I96o, p. 87-9o). Maar er bestaan honderden particuliere 'employment agencies', die wel aan bepaalde voorschriften van het Ministerie van Arbeid moeten voldoen, maar die overigens op commerciële basis zelfstandig opereren. In Marchmont Street, Holborn, Londen, is een particulier arbeidsbemiddelingsbureau gevestigd voor typisten en secretaressen, waar geen gekleurd personeel staat ingeschreven, omdat 'zij niet efficiënt genoeg werken,' en omdat 'werkgevers bang zijn voor moeilijkheden met het overige personeel'. In Tavistock Place, in dezelfde Londense wijk, heeft een bemiddelingsbureau voor huishoudelijk personeel ook geen aanvragen voor gekleurden, hoewel deze juist in die sector werkzaam zijn.

Discriminatie, dat wil zeggen differentiële behandeling van bepaalde immigrantengroepen, behoeft echter niet op rigide vooroordeel tegenover gekleurden te wijzen. Zij kan wijzen op een soort voorzichtige afzijdigheid, die de Brit zich tegenover vreemdelingen voorbehoudt, want als zodanig beschouwt hij de gekleurde immigranten uit de Gemenebestlanden (PATTERson, I963, p. 23, 24). Zo wordt wel eens gezegd dat pensionhoudsters beginnen te 'discrimineren' tussen de verschillende gekleurde groepen in die zin, dat zij liever Pakistani dan Westindiërs huisvesten, omdat de eersten een zo volkomen van het hunne afwijkend cultu- 
reel patroon handhaven, dat zij van deze immigranten geen inbreuk op hun 'privacy' vrezen. ${ }^{1}$

Dat echt kleurvooroordeel wel degelijk in Groot-Brittannië bestaat, wordt intussen door maar weinig Britse sociologen ontkend. Vooroordeel duidt op een irrationele attitude van verwerping, die gebaseerd is op stereotypen. Het kan wijzen op een rigide persoonlijkheidstrek, of op aangeleerde antipathie. Discriminatie en vooroordeel gaan vaak samen, maar noodzakelijk is dit niet (BANTON, I959, p. 30). Voor zover door particuliere bedrijven in GrootBrittannië ten aanzien van gekleurden wordt gediscrimineerd, is er sprake van de voorgewende of echte verwachting dat hun cliënten of hun werknemers er de voorkeur aan geven niet met deze immigranten in nauw contact te komen. Die cliënten en werknemers komen vooral uit de Britse middenklassen.

In de hogere klassen in Groot-Brittannië bestaat kleurvooroordeel niet of nauwelijks. Voldoet de immigrant aan het gestelde exclusiviteitscriterium, bijvoorbeeld is hij uitzonderlijk intellectueel of aesthetisch begaafd, of financiëel zeer vermogend, dan zal hij eerder tot deze kringen dan tot die van de middenklassen toegang verkrijgen.

De middenklassen zijn voor de immigrant het moeilijkst toegankelijk. Dit is zowel in Groot-Brittannië als in Nederland het geval. Het blijkt, dat kleurvooroordeel nauw verweven is met klassebewustzijn en angst voor verlies van status. De Jamaicaanse nieuwkomer die, in zijn eigen land volgens Engelse middenklasse-normen opgevoed, te spoedig meent te zijn aanvaard stoot vaak pijnlijk zijn neus. Het onderscheiden van de in Groot-Brittannië gebruikelijke sociale grenzen en het ontwikkelen van een adequaat verdedigingsmechanisme, maken deel uit van de individuele aanpassing en hersocialisatie van de immigrant.

In de lagere klassen in Groot-Brittannië treedt vooroordeel jegens immigranten uit de Gemenebestlanden eigenlijk alleen op als weerspiegeling van de economische situatie en dit wel het duidelijkst bij een economische recessie. Zowel de aantallen immigranten als hun economisch gedrag kunnen aanleiding worden tot spanningen. De immigrant komt allereerst naar Groot-Brittannië om zoveel geld te verdienen als mogelijk is. Hij wil gaarne overwerken om zijn weekloon te verhogen. In stukwerkbedrijven vindt men geen nieuwkomers: zij moeten zich eerst aan het snelle

1 Mededeling van Beryl Scotr, Ass. Representative The British Council, Amsterdam, juli 1966. 
Europese arbeidstempo leren aanpassen. Om het laatste houden maats en medearbeiders hen voor lui; het eerste kweekt afgunst, want de autochtone Brit, die liefst niet overwerkt, ziet toch zijn maat en vooral zijn ondergeschikte ongaarne met meer loon naar huis gaan dan hijzelf. Bovendien kost het de immigrant weinig moeite, daarheen te trekken waar hij het meest kan verdienen. Zijn Britse collega's zijn gebonden aan hun huis en aan de fabriek waarin zij al vele jaren werken. De immigrant pakt zijn koffertje en verhuist van de levensmiddelenindustrie naar de schoenindustrie en vice versa. Van de plaatsingsmogelijkheden wordt hij door verwanten en landgenoten op de hoogte gesteld. De arbeidssituatie van de Jamaicaanse fabrieksarbeider in Engeland verschilt niet essentiëel van die van zijn Surinaamse collega in Nederland (BAYER, I965; THOLENAAR-VAN RAALTE, I963, p. 36-39).

Door de bedrijfsleiding van grote concerns en overheidsbedrijven in Groot-Brittannië wordt de economische bijdrage van de gekleurde immigranten in de lagere beroepsgroepen als onontbeerlijk beschouwd. Zonder hen zou onder andere de London Transport niet goed kunnen blijven functioneren, daar zij het onaanzienlijke werk verrichten dat de autochtone Britten afwijzen: vier procent van het totale arbeidsleger (eind december I965: 74.0oo man) bebestaat uit gekleurde werknemers. In I959 bedroeg hun aantal 4.000 (GLASS, I960, p. 68). Sedert I955 werkt de onderneming met gekleurd personeel en het succes hiervan is bekend. Dit door het Londense publiek zeer gewaardeerde, voornamelijk Westindische personeel wordt echter door de onderneming streng geselecteerd en schriftelijk getest, onder andere op geschiktheid om met publiek om te gaan. ${ }^{1}$

De gedachte dat kleur en lagere klasse aan elkaar gebonden zijn, vormt een ernstig gevaar voor de toekomstige werkgelegenheid van de zogenaamde 'tweede generatie', de in Groot-Brittannië geboren kinderen van de gekleurde immigranten (PATTERSON, I963, p. 23-24). Zal men deze Britten, die de steun missen van de gedachte aan teruggaan naar hun land van oorsprong, de plaatsen geven waarvoor zij geschikt zijn?

De economische situatie der immigranten kan moeilijk worden losgemaakt van het probleem van de woongelegenheid, dat de Britse regering grote zorgen baart. Aan de woonsituatie der gekleurde minderheden zijn meerdere onderzoekingen gewijd. Van de Westindiërs in Londen is twee-vijfde deel in de beide voorste-

1 Mededeling van C. Goмm, London Transport Executive, april 1966. 
den Brixton en North Kensington geconcentreerd. Daar worden gehele straten met vervallen huizen door Westindiërs bewoond, huizen die eigenlijk al voor afbraak bestemd waren. Het zijn slecht onderhouden, uitgewoonde, ongeriefelijke Victoriaanse huizen die door een blanke of door een gekleurde eigenaar tegen veel te hoge prijzen worden onderverhuurd aan teveel gezinnen per perceel. Deze overbezetting leidt tot ongewenste toestanden en houdt grote gevaren in voor de gezondheid van de bewoners en voor de volksgezondheid (GLASs, I960, p. 37-39).

Tengevolge van het in Engeland nog steeds heersende woningtekort is het moeilijk aan de onbehoorlijke practijken van sommige makelaars en eigenaars (vaak zelf gekleurden) een einde te maken. In Engeland bestaat geen woningdistributiesysteem zoals in Nederland, en bovendien is in Engeland het bewoonde huis meestal eigendom van de bewoner. Menig gezin van gekleurde immigranten weet niettemin deze wijken van concentratie te verlaten, want drie-vijfde deel der Westindiërs woont buiten de genoemde voorsteden Brixton en North Kensington, onder andere in de omringende voorsteden Stockwell, Camberwell of Tooting, respectievelijk in Shepherds Bush of Willesden. Maar deze mensen moeten dan voor een huis een zo hoge koopprijs betalen, dat men een gedeelte ervan gaat onderverhuren om de hypotheek te kunnen aflossen. Dit leidt tot verwaarlozing en ergernis van de buren. Deze verhuizen en hun achtergelaten huis daalt in waarde. De nieuwe middenklasse-koper is niet bereid de verlangde prijs te betalen als hij weet, dat in het huis ernaast een Jamaicaans arbeidersgezin woont. Als de makelaar deze omstandigheid verzwijgt, acht de koper zich bedrogen. En het Westindische gezin voelt zich geisoleerd; men mist het dagelijkse contact met vrienden en verwanten. Daarom aarzelen velen om de concentraties te verlaten (RUCK, I960, p. 99-I00).

Naast de in het voorgaande behandelde aspecten van het immigrantenvraagstuk in Groot-Brittannië en Nederland verdienen zeker ook aandacht de vormen van reactie op de situatie, waarin de immigranten door de migratie zijn komen te verkeren. Deze vormen van reactie kunnen zich onder andere manifesteren in verschillende vormen van protest tegen de ontvangende maatschappij.

In het geval van de Jamaicaanse Londenaars uit de lagere klasse vinden wij als vorm van reactie, naast individuele agressiviteit, onder andere een georganiseerde passiviteit, die al vóór 
Europese arbeidstempo leren aanpassen. Om het laatste houden maats en medearbeiders hen voor lui; het eerste kweekt afgunst, want de autochtone Brit, die liefst niet overwerkt, ziet toch zijn maat en vooral zijn ondergeschikte ongaarne met meer loon naar huis gaan dan hijzelf. Bovendien kost het de immigrant weinig moeite, daarheen te trekken waar hij het meest kan verdienen. Zijn Britse collega's zijn gebonden aan hun huis en aan de fabriek waarin zij al vele jaren werken. De immigrant pakt zijn koffertje en verhuist van de levensmiddelenindustrie naar de schoenindustrie en vice versa. Van de plaatsingsmogelijkheden wordt hij door verwanten en landgenoten op de hoogte gesteld. De arbeidssituatie van de Jamaicaanse fabrieksarbeider in Engeland verschilt niet essentiëel van die van zijn Surinaamse collega in Nederland (BAYER, I965; THOLENAAR-VAN RAALTE, I963, p. 36-39).

Door de bedrijfsleiding van grote concerns en overheidsbedrijven in Groot-Brittannië wordt de economische bijdrage van de gekleurde immigranten in de lagere beroepsgroepen als onontbeerlijk beschouwd. Zonder hen zou onder andere de London Transport niet goed kunnen blijven functioneren, daar zij het onaanzienlijke werk verrichten dat de autochtone Britten afwijzen: vier procent van het totale arbeidsleger (eind december 1965: 74.000 man) bebestaat uit gekleurde werknemers. In 1959 bedroeg hun aantal 4.000 (GLASS, I960, p. 68). Sedert I955 werkt de onderneming met gekleurd personeel en het succes hiervan is bekend. Dit door het Londense publiek zeer gewaardeerde, voornamelijk Westindische personeel wordt echter door de onderneming streng geselecteerd en schriftelijk getest, onder andere op geschiktheid om met publiek om te gaan. ${ }^{1}$

De gedachte dat kleur en lagere klasse aan elkaar gebonden zijn, vormt een ernstig gevaar voor de toekomstige werkgelegenheid van de zogenaamde 'tweede generatie', de in Groot-Brittannië geboren kinderen van de gekleurde immigranten (PATTERSON, I963, p. 23-24). Zal men deze Britten, die de steun missen van de gedachte aan teruggaan naar hun land van oorsprong, de plaatsen geven waarvoor zij geschikt zijn?

De economische situatie der immigranten kan moeilijk worden losgemaakt van het probleem van de woongelegenheid, dat de Britse regering grote zorgen baart. Aan de woonsituatie der gekleurde minderheden zijn meerdere onderzoekingen gewijd. Van de Westindiërs in Londen is twee-vijfde deel in de beide voorste-

1 Mededeling van C. Gомм, London Transport Executive, april 1966. 
den Brixton en North Kensington geconcentreerd. Daar worden gehele straten met vervallen huizen door Westindiërs bewoond, huizen die eigenlijk al voor afbraak bestemd waren. Het zijn slecht onderhouden, uitgewoonde, ongeriefelijke Victoriaanse huizen die door een blanke of door een gekleurde eigenaar tegen veel te hoge prijzen worden onderverhuurd aan teveel gezinnen per perceel. Deze overbezetting leidt tot ongewenste toestanden en houdt grote gevaren in voor de gezondheid van de bewoners en voor de volksgezondheid (GLASs, I96o, p. 37-39).

Tengevolge van het in Engeland nog steeds heersende woningtekort is het moeilijk aan de onbehoorlijke practijken van sommige makelaars en eigenaars (vaak zelf gekleurden) een einde te maken. In Engeland bestaat geen woningdistributiesysteem zoals in Nederland, en bovendien is in Engeland het bewoonde huis meestal eigendom van de bewoner. Menig gezin van gekleurde immigranten weet niettemin deze wijken van concentratie te verlaten, want drie-vijfde deel der Westindiërs woont buiten de genoemde voorsteden Brixton en North Kensington, onder andere in de omringende voorsteden Stockwell, Camberwell of Tooting, respectievelijk in Shepherds Bush of Willesden. Maar deze mensen moeten dan voor een huis een zo hoge koopprijs betalen, dat men een gedeelte ervan gaat onderverhuren om de hypotheek te kunnen aflossen. Dit leidt tot verwaarlozing en ergernis van de buren. Deze verhuizen en hun achtergelaten huis daalt in waarde. De nieuwe middenklasse-koper is niet bereid de verlangde prijs te betalen als hij weet, dat in het huis ernaast een Jamaicaans arbeidersgezin woont. Als de makelaar deze omstandigheid verzwijgt, acht de koper zich bedrogen. En het Westindische gezin voelt zich geisoleerd; men mist het dagelijkse contact met vrienden en verwanten. Daarom aarzelen velen om de concentraties te verlaten (Ruck, I96o, p. 99-100).

Naast de in het voorgaande behandelde aspecten van het immigrantenvraagstuk in Groot-Brittannië en Nederland verdienen zeker ook aandacht de vormen van reactie op de situatie, waarin de immigranten door de migratie zijn komen te verkeren. Deze vormen van reactie kunnen zich onder andere manifesteren in verschillende vormen van protest tegen de ontvangende maatschappij.

In het geval van de Jamaicaanse Londenaars uit de lagere klasse vinden wij als vorm van reactie, naast individuele agressiviteit, onder andere een georganiseerde passiviteit, die al vóór 
Europese arbeidstempo leren aanpassen. Om het laatste houden maats en medearbeiders hen voor lui; het eerste kweekt afgunst, want de autochtone Brit, die liefst niet overwerkt, ziet toch zijn maat en vooral zijn ondergeschikte ongaarne met meer loon naar huis gaan dan hijzelf. Bovendien kost het de immigrant weinig moeite, daarheen te trekken waar hij het meest kan verdienen. Zijn Britse collega's zijn gebonden aan hun huis en aan de fabriek waarin zij al vele jaren werken. De immigrant pakt zijn koffertje en verhuist van de levensmiddelenindustrie naar de schoenindustrie en vice versa. Van de plaatsingsmogelijkheden wordt hij door verwanten en landgenoten op de hoogte gesteld. De arbeidssituatie van de Jamaicaanse fabrieksarbeider in Engeland verschilt niet essentiëel van die van zijn Surinaamse collega in Nederland (BAyer, I965; TholenaAR-VAn RAalte, I963, p. 36-39).

Door de bedrijfsleiding van grote concerns en overheidsbedrijven in Groot-Brittannië wordt de economische bijdrage van de gekleurde immigranten in de lagere beroepsgroepen als onontbeerlijk beschouwd. Zonder hen zou onder andere de London Transport niet goed kunnen blijven functioneren, daar zij het onaanzienlijke werk verrichten dat de autochtone Britten afwijzen: vier procent van het totale arbeidsleger (eind december I965: 74.000 man) bebestaat uit gekleurde werknemers. In I959 bedroeg hun aantal 4.00o (GLASS, I960, p. 68). Sedert I955 werkt de onderneming met gekleurd personeel en het succes hiervan is bekend. Dit door het Londense publiek zeer gewaardeerde, voornamelijk Westindische personeel wordt echter door de onderneming streng geselecteerd en schriftelijk getest, onder andere op geschiktheid om met publiek om te gaan. ${ }^{1}$

De gedachte dat kleur en lagere klasse aan elkaar gebonden zijn, vormt een ernstig gevaar voor de toekomstige werkgelegenheid van de zogenaamde 'tweede generatie', de in Groot-Brittannië geboren kinderen van de gekleurde immigranten (PATTERSON, I963, p. 23-24). Zal men deze Britten, die de steun missen van de gedachte aan teruggaan naar hun land van oorsprong, de plaatsen geven waarvoor zij geschikt zijn?

De economische situatie der immigranten kan moeilijk worden losgemaakt van het probleem van de woongelegenheid, dat de Britse regering grote zorgen baart. Aan de woonsituatie der gekleurde minderheden zijn meerdere onderzoekingen gewijd. Van de Westindiërs in Londen is twee-vijfde deel in de beide voorste-

1 Mededeling van C. Gomm, London Transport Executive, april 1966. 
den Brixton en North Kensington geconcentreerd. Daar worden gehele straten met vervallen huizen door Westindiërs bewoond, huizen die eigenlijk al voor afbraak bestemd waren. Het zijn slecht onderhouden, uitgewoonde, ongeriefelijke Victoriaanse huizen die door een blanke of door een gekleurde eigenaar tegen veel te hoge prijzen worden onderverhuurd aan teveel gezinnen per perceel. Deze overbezetting leidt tot ongewenste toestanden en houdt grote gevaren in voor de gezondheid van de bewoners en voor de volksgezondheid (GLASs, I96o, p. 37-39).

Tengevolge van het in Engeland nog steeds heersende woningtekort is het moeilijk aan de onbehoorlijke practijken van sommige makelaars en eigenaars (vaak zelf gekleurden) een einde te maken. In Engeland bestaat geen woningdistributiesysteem zoals in Nederland, en bovendien is in Engeland het bewoonde huis meestal eigendom van de bewoner. Menig gezin van gekleurde immigranten weet niettemin deze wijken van concentratie te verlaten, want drie-vijfde deel der Westindiërs woont buiten de genoemde voorsteden Brixton en North Kensington, onder andere in de omringende voorsteden Stockwell, Camberwell of Tooting, respectievelijk in Shepherds Bush of Willesden. Maar deze mensen moeten dan voor een huis een zo hoge koopprijs betalen, dat men een gedeelte ervan gaat onderverhuren om de hypotheek te kunnen aflossen. Dit leidt tot verwaarlozing en ergernis van de buren. Deze verhuizen en hun achtergelaten huis daalt in waarde. De nieuwe middenklasse-koper is niet bereid de verlangde prijs te betalen als hij weet, dat in het huis ernaast een Jamaicaans arbeidersgezin woont. Als de makelaar deze omstandigheid verzwijgt, acht de koper zich bedrogen. En het Westindische gezin voelt zich geisoleerd; men mist het dagelijkse contact met vrienden en verwanten. Daarom aarzelen velen om de concentraties te verlaten (Ruck, r960, p. 99-100).

Naast de in het voorgaande behandelde aspecten van het immigrantenvraagstuk in Groot-Brittannië en Nederland verdienen zeker ook aandacht de vormen van reactie op de situatie, waarin de immigranten door de migratie zijn komen te verkeren. Deze vormen van reactie kunnen zich onder andere manifesteren in verschillende vormen van protest tegen de ontvangende maatschappij.

In het geval van de Jamaicaanse Londenaars uit de lagere klasse vinden wij als vorm van reactie, naast individuele agressiviteit, onder andere een georganiseerde passiviteit, die al vóór 
emigratie uit Jamaica bij de immigranten bekend is als vorm van protest tegen armoede en frustratie, en die ook in de nieuwe onzekere situatie toepassing vindt. De Jamaicanen in Londen bezitten voor emotionele beleving binnen hun groep alleen hun sectarische religieuze congregaties. De congregaties van de Jamaicanen uit de lagere klassen zijn voor het merendeel uit de Verenigde Staten van Amerika geïmporteerde Pinksterbewegingen, waarvan de diensten Evangelisch zijn, maar met onmiskenbare cultustrekken (GLass, I960, p. 203). Zij worden geleid door een prediker. Als plaats van samenkomst, de 'gospel hall' - er zijn circa acht gospel halls in Londen - dienen bijvoorbeeld twee ontruimde kamers in een sousterrain van één der vervallen Victoriaanse huizen. 'Church of God' staat er te lezen op een verregend houten bord aan de ingang van het tuinhek van een verwaarloosd huis in Effra Road, Brixton. De congregatie is gezeten op bruine caféstoelen. Er wordt zowel in de Zondagsschool als in de daarop aansluitende Zondagsdienst veel gezongen, met guitaarbegeleiding, uit een gezangboek. De preek handelt over een stuk Bijbeltekst, door de prediker uitgelegd in een vraag-en-antwoord ritme en verlevendigd door nu en dan een forse stemverheffing. De congregatie neemt actief deel met uitroepen als 'yes, God,' 'no, God,' 'wonderful Jesus,' met in de handen klappen, ceremoniëel wenen en huiveren.

De religieuze beleving is het terrein waarop de Jamaicaanse immigranten uit de lagere klassen de Engelse cultuur afwijzen: de sfeer van de Engelse kerkdiensten vinden zij te koud. Aangezien een groot deel dezer Jamaicanen zeer religieus is, dienen die eigen congregaties vele doelen tegelijk. Naast handhaving van sobere zeden in een nieuwe wereld vol verleidingen, bevordering van de interne integratie en vervulling van een recreatieve functie, geven zij uitdrukking aan een passief protest tegen de ontvangende maatschappij.

Bij de vergelijkbare groep Surinamers in Nederland manifesteert zich de reactie op hun maatschappelijke situatie in een heel andere vorm van protest. Bij deze groep en hun leiders is eerder sprake van georganiseerde strijdvaardigheid, rationeel gericht op wijzigingen in het Statuut voor het Koninkrijk van I954. In de laatste jaren zijn door desintegratie, respectievelijk hergroepering van enkele vrijwillige verenigingen, de scherpste kanten er wat afgesleten bij de jongeren uit de intellectuelen- en middenklasse, die de activiteiten moeten leiden. Deze ontwikkeling is het gevolg van gebrek aan opvolgers van topleiders, toename van de 
Surinaamse immigrantenbevolking tot circa 12.000 personen, en meer contact tussen gematigde groepen en militante jongeren. Maar de opvatting dat Nederland een schuld aan Suriname te vereffenen heeft - waarvan de meeste Nederlanders zich niet bewust zijn - vormt nog steeds een centraal thema in het nationalistische standpunt. Met behulp van deze vereffeningsdoctrine heeft menige immigrant zich in de eerste moeilijke periode van hersocialisatie in Nederland van vele gevoelens van teleurstelling weten te bevrijden.

Wat voor een aantal Surinaamse immigranten uit de lagere klassen de politieke bijeenkomst is, waar zij zich affectief bij betrokken voelen, is voor vele Jamaicaanse Londenaars de religieuze congregatie. Beide organisatievormen zijn te beschouwen als vormen van protest tegen de Nederlandse, respectievelijk de Britse samenleving en tegelijk als vormen van escapisme in een onzekere situatie: zij zijn een index voor de marginaliteit van de betrokken groepen immigranten.

Het in de aanvang genoemde Witboek van de Britse regering van augustus r 965 eindigt met een beroep op het Britse volk om eraan mede te werken, dat het proces van absorptie van de immigranten uit de Gemenebestlanden in de Britse samenleving zonder frictie en met wederzijds begrip en tolerantie wordt bespoedigd.

$\mathrm{Er}$ is onlangs een Act of Conciliation, een soort bemiddelingswet, tot stand gekomen die reeds in werking is getreden. Wie discriminerende practijken ten aanzien van immigranten toepast in openbare gelegenheden, bij verhuur van woonruimte of verkoop van huizen, bij tewerkstelling en in verwante situaties, handelt onwettig en kan voor de rechter worden gedaagd. Er wordt geen straf opgelegd, maar de beklaagde moet zich zien te rechtvaardigen en de rechter verzoekt hem zijn houding te herzien. Van publiciteit, verlies van goede naam en het odium de wet ongehoorzaam te zijn, wordt een preventief effect verwacht. ${ }^{1}$ De Britten staan bekend als een wet-eerbiedigend volk, dus is die verwachting niet ongegrond. De vraag is alleen: zal de benadeelde of namens hem een getuige, inderdaad een klacht indienen? De goede naam van Groot-Brittannië is gemoeid met het succes van zijn regering, om de traditie van klasse- en kleurvooroordeel bij een deel van zijn bevolking radicaal te doorbreken, desnoods door middel van wetgeving.

1 Mededeling van RoBIN H. WARD, socioloog, Universiteit van Manchester, september 1966. 
Tijdens een conferentie georganiseerd door The Institute of Race Relations (London) en The Royal Anthropological Institute (London), en gehouden te Londen van 20 april tot en met 22 april I966, kwamen onder andere de problemen ter sprake van de concentratie van immigrantengezinnen in bepaalde wijken van de Engelse industriesteden en de daaruit voortvloeiende concentratie van immigrantenkinderen op de scholen in die wijken. Voor de Engelse industriële maatschappij is een grotere mate van integratie van haar gekleurde en blanke minderheden noodzakelijk, maar wat is wenselijker voor de immigrant: volledige assimilatie, of accommodatie aan een segment van die maatschappij? Assimilatie betekent dat de migrant een zo volledig mogelijke identificatie met, en verinnerlijking van de in de nieuwe maatschappij algemeen geldende normen bereikt. Accommodatie aan een segment van die nieuwe maatschappij echter wil zeggen, dat hij zich voor zijn - meestal economische - doeleinden voor zover nodig aanpast aan normen, die gangbaar zijn in het segment van de nieuwe samenleving waarin hij die doelen denkt te kunnen verwezenlijken (bijvoorbeeld de fabriek).

In dit verband was de aandacht van de Britse sociologen op de conferentie vooral gericht op de situatie van de thans opgroeiende tweede-generatie immigranten. Voor de immigrantenkinderen behoren de beste onderwijskrachten beschikbaar te zijn, maar juist op de scholen in die vervallen wijken worden de minder goede en onbevoegde leerkrachten, onder wie veel personeelswisseling voorkomt, aangesteld. Men was van mening, dat er - naast een adequaat huisvestingsbeleid van de lokale overheden - speciale voorzieningen moeten komen voor immigrantenkinderen op school, opdat zij dezelfde kansen als Engelse kinderen zullen hebben bij het verlaten van de school. De opleiding van speciale onderwijskrachten dient een geëigende training in attituden tegenover immigranten te omvatten. Een voorbeeld van een dergelijke training biedt een opleidingsinstituut voor maatschappelijk werkers in Medina Road, Noord-Londen. De cursisten zijn verplicht, de door de 'warden' georganiseerde 'social evenings' in gezelschap van gekleurde medecursisten door te brengen. Dat een deel der Engelse cursisten zich hieraan hardnekkig tracht te onttrekken, toont de wenselijkheid aan van een training in bovenbedoelde zin. ${ }^{1}$

$\mathrm{Al}$ deze aanbevelingen worden in het Witboek van de Britse re-

1 Mededeling van Maria Th. Renner, psychologe, Universiteit van Bonn, april r966. 
gering tot uitdrukking gebracht. De huidige situatie van de Surinaamse immigranten in Nederland vereist dergelijke ingrijpende maatregelen van overheidswege niet. In Amsterdam bestaat wel bij alleenstaande en gehuwde Surinaamse kamerbewoners de tendens, in 'Oost' huisvesting te zoeken, maar dichte concentraties van immigrantengezinnen konden, dankzij het woningdistributiebeleid van de Nederlandse Gemeenten, niet ontstaan. Daarmede wordt Nederland een reeks van zorgwekkende consequenties bespaard, waarmede men in Groot-Brittannië nog wel enige tijd zal worstelen.

\section{SUMMARY}

The problems resulting from the influx and integration in Great Britain of large numbers of recent immigrants from Commonwealth countries with predominantly coloured populations, have induced the British Government to enact the Commonwealth Immigrants Act of August 1965. In a White Paper the terms of admission into Great Britain are laid down and action by local authorities is recommended to further a satisfactory integration of the Commonwealth immigrants in British society.

Four aspects of Great Britain's integration policy are being discussed in the present paper: the prevention of social tensions; the refusal of Employment Exchanges to accept applications for labour by employers who attach discriminatory conditions; the prevention of undesirable concentrations of coloured immigrants in certain areas; and the maintenance of high standards of education at all schools. In relation to these aspects the social situation of a specific group of West Indian immigrants in London, the lower-class Jamaicans, has been compared with a similar immigrant group in The Netherlands, the lower-class Surinamese. A striking difference between these two groups of immigrants is the presence of political and recreative voluntary associations among the Surinamese, whereas these are absent among the Jamaicans. The latter, however, have founded their own religious congregations. Both the political and recreative associations of the Surinamese and the religious congregations of the Jamaicans are expressions of the immigrants' protest against the host society.

Special attention is being paid by British sociologists and authorities to the situation and opportunities of immigrant children, the so-called 'second generation'. Through legislation, like e.g. the Act of Conciliation, Great Britain aims at achieving a satisfactory integration of its Commonwealth immigrants. 


\section{LITERATUUR}

Banton, Michael: The Coloured Quarter. Negro immigrants in an English city. London, 1955 .

Banton, Michael: White and Coloured. The behaviour of British people towards coloured immigrants. London, 1959.

BAyer, A. E.: Surinaamse Arbeiders in Nederland. Assen, 1965.

Doorn, J. A. A. van: De Proletarische Achterhoede. Meppel, I954.

Doorn, J. A. A. van: Wijk en Stad: reële Integratiekaders? In Prae-adviezen voor het Congres over Sociale Samenhangen in Nieuwe Stadswijken van het Instituut voor Sociaal Onderzoek van het Nederlandse Volk. Amsterdam, I955.

EgGinton, Joyce: They seek a Living. London, 1957.

Eisenstadt, S. N.: The Absorption of Immigrants. London, 1954.

Ellemers, J. E. : Aanpassing van Immigranten. In Het Sociale Leven in al zijn Facetten. Deel II. Sleutel tot de moderne maatschappelijke problematiek. Assen, $195^{8}$.

Glass, Ruth: Newcomers. The West Indians in London. London, 1960.

Griffith, J. A. G. \& Henderson, Judith \& Usborne, Margaret \& Wood, Donald: Coloured Immigrants in Britain. Oxford University Press, 1960.

Hofstede, B. P.: 'De Gaande Man', gronden van de emigratiebeslissing. 's-Gravenhage, $195^{8}$.

Hollander, A. N. J. Den: Het Andere Volk. Rede. Leiden, I946.

Hollander, A. N. J. DEN: 'Cultuurconflict' als sociologisch begrip en als verschijnsel. In Sociologisch Jaarboek 8, 1957.

Immigration from the Commonwealth (White Paper), presented to Parliament by the Prime Minister by Command of Her Majesty, August 1965, London, Her Majesty's Stationary Office, Cmnd. 2739.

Jamaica: The Making of a Nation. Pamphlet prepared for the British Information Service. London, April 1962.

Jephcott, Pearl: A Troubled Area. Notes on Notting Hill. London, 1964.

KRUIJER, G. J.: Suriname en zijn Buurlanden. Lichtplekken in het oerwoud van Guyana. Meppel, r951.

Kruijer, G. : Urbanisme in Suriname. In Tijdschr. Koninkl. Nederl. Aardr. Genootschap 68, I95I.

Lamming, George: The Pleasures of Exile. London, 1960.

LIER, R. A. J. vAN : Samenleving in een Grensgebied. 's-Gravenhage, 1949.

LIER, R. A. J. vAN: Ontwikkeling en Karakter van de West-Indische Maatschappij. Rede. Leiden, 1950. 
LIER, R. A. J. van: Cultuurconflict in de heterogene samenleving. In Sociologisch Jaarboek 8, 1957.

Little, K. L.: Negroes in Britain. A study of racial relations in English society. London, I947.

Little, Kenneth: Race and Society. UNESCO pamphlet. Paris, 1952.

Patterson, Sheila : Dark Strangers. A sociological study of the absorption of a recent West Indian migrant group in Brixton, South London. London, 1963.

Richmond, A. H.: Colour Prejudice in Britain. A study of West Indian workers in Liverpool $1941-1951$. London, 1954.

Ruck, S. K. (ed.): The West Indian comes to England. A report prepared for the Trustees of the London Parochial Charities by the Family Welfare Association. London, I960.

Simpson, G. E.: Jamaican Revivalist Cults. In Social and Economic Studies 5, 1956.

TholenaAr-van RaAlte, J.: Migratie en Integratie van Surinamers in Nederland. Amsterdam, 1963 (onuitgegeven),

Williams, ERIC: The Negro in the Caribbean. Washington D.C., I942. 